\title{
Avian Range Extension Northward to Deception Bay, Quebec
}

\author{
PATRICK J: WEATHERHEAD' and J. ROGER BIDER' \\ 'Department of Renewable Resources, Macdonald Campus of McGill University, Ste. Anne de \\ Bellevue, Quebec H9X 1C0
}

From 19 to 23 July 1979, the authors conducted surveys by foot of the avifauna of Deception Bay, Quebec $\left(62^{\circ} 07^{\prime} \mathrm{N}, 74^{\circ}, 40^{\prime} \mathrm{W}\right)$. Tree Sparrows (Spizella arborea) were heard singing in several locations, 2 inactive nests were found (one containing 1 egg and 1 dead nestling), and one bird was observed feeding a fledgling. Godfrey (1966) gives the range of the Tree Sparrow in northern Quebec as extending in the Ungava Peninsula to Povungnituk River, Leaf River and Fort Chimo. The observations at Deception Bay indicate an extension of their range to Hudson Strait. This is similar to the range extension for White-crowned Sparrows (Zonotrichia leucophrys) reported by Ouellet and Bider (1973).

Sightings and evidence of Tree Sparrows were limited to areas of mixed shrub habitat dominated by Dwarf Birch (Betula glandulosa) and several species of willow (Salix spp.). This habitat has a very restricted distribution in the Deception Bay region, being found only at low altitudes and only in riparian areas or on seepage slopes below areas of traditional snow accumulation. Also associated only with this habitat were redpolls (Carduelis sp.),Savannah Sparrows (Passerculus sandwichesis) and White-crowned Sparrows (Zonotrichia leucophrys). The habitat specificity of Tree Sparrows and White-crowned Sparrows in combination with the limited distribution of this habitat probably accounts for the recent recognition that their ranges extend to the top of the Ungava Peninsula. It is possible that more extensive surveys of these habitat patches may reveal the presence of other species whose ranges are traditionally considered not to extend much beyond the tree line.

A sighting warranting further investigation was that of a pair of Hoary Redpolls (C. hornemanni). Although the birds were seen clearly, further observations are required because of the facility of confusing the 2 redpoll species. The range of Hoary Redpolls might be expected to extend through the Ungava Peninsula, however, as at present this region represents a major discontinuity in their range (Godfrey, 1966).

\section{REFERENCES}

GODFREY, W. E. 1966. The birds of Canada. National Museum of Canada, Bulletin Number 203. $428 \mathrm{pp}$.

OUELLET, H. and J. R. BIDER. 1973. White-crowned Sparrow breeding at Deception Bay, Nouveau-Quebec. Canadian Field-Naturalist 87: 321. 